\title{
Bimbingan Karir dalam Menumbuhkan Motivasi Entrepreneurship Peserta Didik
}

\author{
Bili Hakiki Jenawi* \\ Jurusan Bimbingan dan Konseling Islam, UIN Sunan Gunung Djati, Bandung \\ *Email:billyhakiki1@gmail.com
}

\begin{abstract}
ABSTRAK
Penelitian ini bertujuan untuk mengetahui bagaimana proses, program dan hasil dari bimbingan karir dalam menumbuhkan motivasi Entrepreneurship peserta didik di Jampang Kulon Sukabumi. Metode penelitian ini menggunakan metode direct (metode langsung) melalui diskusi bersama dua arah dari pembimbing kepada peserta didik dan dari peserta didik kepada pembimbing, kemudian pula melalui ceramah, metode observasi mengamati secara langsung dengan pihakpihak peguruan tinggi, metode konsultasi yakni setelah melakukan observasi peserta didik diberikan kesempatan berkonsultasi langsung dengan pihak-pihak dari perguruan tinggi. Hasil penelitian ini menunjukan pelaksanaan bimbingan karirdi Sekolah Menengah Kejuruan Al-Mubarokatusaa'adillah secara tidak langsung telah mempraktikkan kegiatan bimbingan karir kepada para peserta didik. Setiap jenis bimbingan karirnya juga mampu menginspirasi dan memberi semangat kepada para peserta didik untuk tetap percaya diri bahwa mereka bisa memasuki berbagai jenis dunia kerja meskipun tidak mempunyai banyak keahlian. Karena dengan adanya bimbingan karir ini tentu para peserta didik akan siap ketika melanjutkan kehidupan di dalam bermasyarakat, adapun indikator Entrepreneurshipnya : a) Inovatif yang artinya memperkenalkan suatu yang baru, b) Kreatif yang artinya memiliki kemampuan untuk menciptakan atau menghasilkan sesuatu yang baru, dan c) Produktif yang berarti kemauan untuk menghasilkan sesuatu atau banyak mendatangkan sesuatu hasil dari berkarya.
\end{abstract}

Kata Kunci: Bimbingan Karir; Motivasi; Entrepreneurship

\section{ABSTRACT}

This paper aims to find out how the process, the program and the results of career guidance in fostering motivation Entrepreneurship learners in JampangKulonSukabumi. This research method using direct method through two way discussion from supervisor to learners and from 
learners to mentors, then also through lecture, observation method observed directly with the parties of high learning, consultation method that is after observation learners are given the opportunity to consult directly with the parties from the college. The results of this study show the implementation of career guidance in Vocational High School Al-Mubarokatusaa'adillah indirectly has been practicing career guidance activities to the learners. Each type of career guidance is also able to inspire and encourage the learners to remain confident that they can enter various types of work world even though they do not have much expertise. Because with the guidance of this career of course the learners will be ready when continuing life in the community, as for the indicator Entrepreneurship: a) Innovative means to introduce a new, b) Creative which means have the ability to create or produce something new, and c) Productive which means willingness to produce something or a lot to bring something result from work.

Keywords: Career Guidance, Motivation, Entrepreneurship

\section{PENDAHULUAN}

Setiap orang pasti membutuhkan pekerjaan untuk memenuhi segala kebutuhan hidupnya. Baik kebutuhan primer, sekunder, dan kebutuhan-kabutuhan lainnya. Kebutuhan tersebut semakin hari tentulah semakin banyak saja. Hal ini dikarenakan perkembangan zaman semakin kompleks dan maju. Kebutuhankebutuhan tersebut menuntut setiap individu untuk mencari uang untuk mencukupi kehidupan. Dengan segala cara seseorang harus memiliki bekal untuk menjalani kehidupan nyata yang penuh masalah tentang pemenuhan kebutuhannya. Dengan begitu jika seseorang tidak siap untuk menghadapi kehidupan yang seperti itu maka bukan tidak mungkin individu tersebut tidak akan dapat bertahan dalam kehidupannya. Untuk mengantisipasi permasalahan tersebut tentunya seseorang harus memiliki keterampilan sebagai bekal menjalani kehidupan dimasa yang akan datang. Keterampilan yang dimiliki seseorang itu nantinya akan digunakan untuk memperoleh uang, baik dengan bekerja di perusahaan orang lain maupun dengan membuka usaha-usaha sendiri sesuai dengan bekal keterapilan yang individu miliki.

Bimbingan karir adalah bimbingan dalam mempersiapkan diri menghadapi dunia kerja, dalam memilih lapangan kerja atau jabatan/profesi tertentu serta membekali diri supaya siap memangku jabatan itu, dan dalam menyesuaikan diri dengan berbagai tuntutan dari lapangan pekerjaan yang dimasuki. Bimbingankarir juga dapat dipakai sebagai sarana pemenuhan kebutuhan perkembangan peserta didik yang harus dilihat sebagai bagian integral dari program pendidikan yang diintegrasikan dalam setiap pengalaman belajar bidang studi (Winkel, 2005: 114).

SMK merupakan lembaga pendidikan yang mencetak tenaga terampil 
untuk mempersiapkan diri dalam memasuki dunia kerja dengan pemenuhan kompetensi diberbagai bidang, kegiatan bimbingan karir yang dilakukan di SMK Al-Mussa menggunakan tiga kegiatan pokok. Pertama di kelas, dalam kegiatan Bimbingan Karir di kelas, usaha-usaha yang bisa dilakukan berupa: memberikan informasi secara luas kepada para peserta didik tentang karir yang akan ditempuhnya, memberikan informasi tentang klasifikasi karir, memberikan informasi dan membantu peserta didik dalam memilih karirnya setelah sudah lulus. Kedua di ruang bimbingan, diwujudkan dalam beberapa bentuk kegiatan, di antaranya: mengadakan rapat koordinasi tentang pelaksanaan Bimbingan Karir, mengadakan konsultasi dengan pihak-pihak yang terlibat dalam pelaksanaan Bimbingan Karir, menyusun program Bimbingan Karir. Ketiga di luar kelas atau sekolah, dapat diwujudukan dengan mengumpulkan informasi tentang berbagai pekerjaan, jabatan, atau karir yang ada dan tersebar di masyarakat, mengumpulkan informasi tentang keadaan, kekayaan dan rencana perkembangan daerah, menyampaikan kepada orang tua siswa, instansi dan masyarakat tentang hal-hal yang berkenaan dengan pelaksanaan Bimbingan Karir.

SMK Al-Mussa adalah Sekolah yang didalamnya terdapat peserta didik yang dibentuk untuk memiliki keterampilan namun kebanyakan peserta didiknya mungkin belum mengetahui tentang keterampilan yang dimiliki sehingga membutuhkan bimbingan karir. Hal ini mungkin terjadi oleh peserta didik di SMK Al-Mussa. Penjelasan seputar SMK Al-Mubarokatusa'adillah yang disingkat Al-Mussa, ialah sekolah kejuruan yang berbasis agama Islam, SMK Al-Mussa memiliki program berbasis agama Islam seperti shalat dzuhur berjamaah dan tadarus bersama, yang dilakukan oleh peserta didik. Di SMK ini pun memberikan pembekalan kepada peserta didik dengan berbagai keterampilan seperti mengajarkan keahlian-keahlian yang dapat membantu dan menambah wawasan dalam hal agama, kejuruan, sosial, ekonomi dan budaya.

Kegiatan bimbingan karir yang diadakan di SMK Al-Mussa salasatunya yaitu bimbingan karir motivasi yang di pandu oleh guru BK, waktu pelaksanaanya seminggu lima kali dan disesuaikan dengan jadwal tiap kelas. memberikan penjelasan tentang pentingnya bimbingan karir di SMK Al-Mussa, Peneliti lebih memfokuskan untuk meneliti kelas XII yang berjumlah 38 orang. Kegiatan dilakukan pada pagi-pagi hari sebelum masuk yang namanya apel atau pembinaan, materi yang diberikan yaitu bimbingan belajar, bimbingan pribadi, dan bimbingan karier tentang motivasi agar keinginan peserta didik setelah lulus tercapai, sedangkan bentuk yang digunakannya melalui konseling individu yang permasalahannya tergantung dari peserta didiknya dan peserta didik ditanya satu persatu tentang permasalahannya, Lalu setelah peserta didik menyampaikan 
permasalahannya guru BK memberi motivasi kepada peserta didik agar peserta didik tidak kebingungan dan mendapatkan jalan keluarnya.

Dengan diadakannya bimbingan karir ini bertujuan untuk memberikan pengetahuan, keterampilan, dan sekaligus membentuk sikap-sikap entrepeneurship bagi peserta didik yang ada di SMK Al-Mussa. Setelah peneliti mewawancarai salasatu guru BK, peneliti juga mewawancarai beberapa peserta didik kelas XII (duabelas). Ketika peneliti bertanya kepada peserta didik tentang rencana setelah mereka lulus dari SMK Al-Mussa, sebagian dari mereka menjawab bingung mau melanjutkan kemana. Beberapa peserta didik menjawab ingin menikah, ada yang ingin bekerja di pabrik dan ada pula yang ingin meneruskan ke perguruan tinggi (kuliah). Tapi sedikit peserta didik yang menjawab ingin berwirausaha, padahal bimbingan karir sudah diberikan kepada peserta didik, lantas apa yang menyebabkan kurangnya motivasi peserta didik dalam hal entrepeneurship (berwirausaha).

Dari latar belakang masalah tersebut rumusan masalah yang diajukan adalah bagaimana proses pelaksanaan bimbingan karir dalam menumbuhkan motivasi Entrepreneurship peserta didik di SMK Al-Mussa? Bagaimana program bimbingan karir dalam menumbuhkan motivasi Entrepreneurship peserta didik di SMK Al-Mussa? Bagaimana hasil bimbingan karir dalam menumbuhkan motivasi Entrepreneurship peserta didik di SMK Al-Mussa?

Adapun penelitian terdahulu menunjukkan bahwa program bimbingan karir terbukti efektif untuk meningkatkan kematangan karir siswa sehingga layak untuk diterapkan dalam layanan Bimbingan dan Konseling (Juwitaningrum, 2016) selain itu layanan bimbingan karir efektif dalam peningkatan kematangan eksplorasi karir siswa yang menjadi subjek penelitian (Khairun, Sulastri \& Hafina, 2016). Defriyanto \& Purnamasari (2016) menyebutkan bahwa ada pengaruh layanan informasi karir dalam maningkatkan kematangan karir efektif untuk meningkatkan kematangan karir pada peserta didik di madrasah aliyah qudsiyah Kotabumi Lampung Utara. Adapun penelitian yang dilakukan Setiawaty, Diningrat \& Fajar (2017) menunjukkan bahwa bimbingan karir melalui kegiatan keterampilan yang diberikan kepada warga binaan setelah diberikan pelatihan dan pengetahuan berbagai macam keterampilan serta mengenal minat bakat yang dimana itu sesuai dengan teori bimbingan karir yang mempunyai keterampilan serta mengenal minat bakat yang ada pada diri sendiri. Selanjutnya penelitian yang dilakukan oleh Sofiah (2018) ditemukan bahwa fungsi bimbingan karir menghasilkan hubungan yang positif serta dapat mempengaruhi dalam membantu dan mengembangkan minat siswa melanjutkan pendidikan ke perguruan tinggi. Sejalan dengan itu, penelitian yang dilakukan 
oleh Sani (2018) mengungkapkan bahwa program layanan infromasi karir memberikan pengaruh positif yang signifikan terhadapperhatian, perasaan senang, dan aktivitas berwirausaha remaja.

Metode penelitian ini menggunakan metode metode direct (metode langsung) melalui diskusi bersama dua arah dari pembimbing kepada peserta didik dan dari peserta didik kepada pembimbing, kemudian pula melalui ceramah, metode observasi mengamati secara langsung dengan pihak-pihak peguruan tinggi, metode konsultasi yakni setelah melakukan observasi peserta didik diberikan kesempatan berkonsultasi langsung dengan pihak-pihak dari perguruan tinggi.

\section{LANDASAN TEORITIS}

Teori yang dijadikan landasan dalam penelitian ini adalah teori bimbingan dalam mempersiapkan diri menghadapi dunia pekerjaan, dalam memilih lapangan pekerjaan atau jabatan/profesi tertentu serta membekali diri supaya siap memangku jabatan itu, ataupun juga melanjutkan ke jenjang yang lebih tinggi perguruan tinggi dan dalam menyesuaikan diri dengan berbagai tuntutan dari lapangan perkerjaan yang telah dimasuki. Mengutip dari (Winkel, 2004: 83).

Dua intisari terpenting dalam bimbingan karir yaitu yang pertama bahwa bimbingan karir merupakan proses membantu individu dalam memahami dan menerima diri sendiri dan yang kedua membantu memahami sekaligus menyesuaikan diri dengan dunia kerja nyata. Dengandemikianhal yang terpenting dalam bimbingan karir adalah adanya pemahaman, penerimaan, dan penyesuaian diri baik terhadap dirinya sendiri maupun terhadap dunia kerja. Bimbingan karir bisa bermakna sebagai suatu bantuan yang diberikan pembimbing kepada yang dibimbing (peserta didik) dalam menghadapi dan memecahkan masalah karir mereka nantinya (Nugrahawati, 2009: 107).

Bimbingan karir adalah usaha bimbingan dalam membantu peserta didik untuk mengatasi kesulitan dalam bidang karir. Bentuk bimbingan ini misalnya memberikan informasi-informasi tentang pekerjaan, perguruan tinggi, ke perusahaan, cara melamar pekerjaan, atau cara memilih dan menentukan karir dan sebagainya. Lebih lanjut tentang pengertian karir adalah perkembangan dan kemajuan seseorang dalam kehidupannya, baik dalam pendidikan/belajar, pekerjaan, jabatan, maupun kegiatan hidup lainnya (Elfi, 2012: 51).

Bimbingan karir juga sebagai suatu proses bantuan, layanan, dan pendekatan terhadap individu, (speserta didik/remaja), agar individu yang 
bersangkutan dapat mengenal dirinya, dan mengenal dunia kerja merencanakan masa depannya dengan bentuk kehidupan yang diharapkannya, untuk menentukan pilihannya dan mengambil suatu keputusan bahwa keputusan tersebut adalah yang paling tepat, sesuai dengan keadaan dirinya dihubungkan dengan persyaratan-persyaratan dan tuntutan pekerjaan/karir yang dipilihnya (A. Ghani 2012: 129).

Berdasarkan hasil penelitian sebelumnya dengan judul Hubungan Pelaksanaan Pengembangan karir terhadap motivasi kerja karyawan Departemen Human Resource PT. Panasonic Shikoku Electronicts Batam yang di teliti oleh Julian Ramadhan. Hasil penelitian ini menunjukan bahwa ada indikator keberhasilan dalam pelaksanaan motivasi pengembangan kerja karyawan, walaupun target yang diinginkan belum sesuai. Terbukti dengan adanya motivasi pengembangan kerja, pengembangan karir karyawan mengalami perubahan walaupun baru pada aspek kognitif, karena setelah mengikuti motivasi pengembangan kerja karyawan.

Maka hubungan pelaksanaan pengembangan karir terhadap motivasi kerja karyawan sangat diperlukan dan menduduki peran yang sangat, karena berhubungan dengan baik dan tidaknya pengebangan karir karyawan Departemen Human Resource PT. Panasonic Shikoku Electronicts Batam, sedangkan hasil dari peneliti yang sekarang dapat dilihat bahwa setiap jenis bimbingan karir yang diadakan di SMK Al-Mussa mampu menginspirasi dan memberi semangat kepada para peserta didik untuk tetap percaya diri bahwa mereka bisa memasuki berbagai jenis dunia kerja meskipun mereka tidak mempunyai banyak keahlian..

Salah satu teori yang berkaitan dengan teori bimbingan karir adalah yang dikemukakan oleh Donald Super. Tahap perkembangan karir menurut Super, (Miharja, 2015: 142-144) yaitu: a. Tingkat pertumbuhan (sejak lahir-14 tahun) b. Tahap eksplorasi (15-24 tahun) c. Tingkat pengukuhan (25-44 tahun) d. Tingkat pemeliharaan (45-64 tahun) e. Tingkat kemerosotan (65 tahun keatas).

Berdasarkan pemaparan di atas Teori Super menekankan tiga hal, yaitu perbedaan individu, konsep diri dan konsep perkembangan. Menurut Super, proses perkembangan kejuruan seseorang dibagi pada dua tingkat. Pertama adalah tingkat eksplorasi yang terdiri dari tingkat-tingkat kecil seperti tingkat tentatif, tingkat transisi dan tingkat percobaan tanpa komitmen. Tingkat kedua adalah tingkat pembentukan dua tingkat kecil, yaitu tingkat percobaan yang berkomitmen dan tingkat kecil kemajuan.

Tujuan bimbingan karir adalah membantu individu memperoleh 
kompetensi yang diperlukan agar dapat menemukan perjalanan hidupnya dan mengembangkan karir ke arah yang di pilihnya secara optimal dan memberikan gambaran yang utuh tentang persyaratn suatu jabatan tertentu sehingga siswa dapat memahami diri, mampu menentukan arah pilihan karir dan pada akhirnya membantu siswa dalam merancang masa depannya. Selain itu siswa dapat siap kerja dan memiliki sikap kemandirian yang dapat diandalkan mampu untuk menghadapi persaingan era globalisasi dan tantangan masa depan karier serta mencetak tenaga terampil untuk mempersiapkan diri dalam memasuki dunia kerja dengan pemenuhan kompetensi di berbagai pengembangan (Rahma, 2015:16).

Pengembangan karir adalah peningkatan pribadi yang dilakukan seseorang untuk mencapai suatu rencana karir dan peningkatan oleh departemen personalia untuk mencapai suatu rencana kerja sesuai dengan jalur atau jenjang organisasi. Jadi betapa pun baiknya suatu rencana karir yang telah dibuat oleh seorang pekerja disertai oleh suatu tujuan karir yang wajar dan realistik, rencana tersebut tidak akan menjadi kenyataan tanpa adanya pengembangan karir yang sistematik dan programatik (I Komang A. dkk 2012).

Berdasarkan uraian tersebut dapat ditarik kesimpulan bahwa perkembangan karir itu dimulai dari tahap pertumbuhan yaitu sejak lahir hingga tahap kemerosotan yaitu jangka waktu yang hampir mendekati masa pensiun. Pada tahap ini individu lebih mementingkan pemeliharaan jabatan daripada memperbaikinya.

Konseling pendidikan jauh lebih berkembang di Indonesia dibanding konseling psikologis sehingga menimbulkan kesan dangkal seolah-olah dunia bimbingan dan konseling di Indonesia hanya milik bidang pendidikan. Hal ini dapat dimengerti karena konseling yang pertama kali berkembang sejak tahun 1963 adalah konseling pendidikan ditandai dengan dibukanya Jurusan Bimbingan dan Penyuluhan di IKIP, tahun 1975 didirikan Ikatan Petugas Bimbingan Indonesia (IPBI) yang sekarang menjadi Asosiasi Bimbingan dan Konseling Indonesia (ABKIN).

Berkaitan dengan pengertian motivasi, beberapa psikolog menyebut motivasi sebagai konstruk hipotesis yang digunakan untuk menjelaskan keinginan, arah, intensitas, dan keajegan perilaku yang diarahkan oleh tujuan. Motivasi berwirausaha pada peserta didik yaitu dorongan atau usaha peserta didik untuk melakukan upaya kreatif, inovatif dan bermanfaat dengan jalan mengembangkan ide dan sumber daya untuk menemukan peluang dan perbaikan hidup, serta terjun dalam persaingan bisnis (Tukseroh, 2013: 139). 
Entrepeneurship adalah padanan kata dari kewirausahaan dalam bahasa Indonesia, unternehmer dalam bahasa Jerman, ondernemen dalam bahasa Belanda, Kata entrepreneur berasal dari bahasa perancis, yaitu entreprende yang berarti petualang, pengambil resiko, kontraktor, pengusaha (orang yang mengusahakan suatu pekerjaan ertentu), dan pencipta yang menjual hasil ciptaannya (Hendro, 2011: 29).

Membangun citra atau publikasi positif merupakan prestasi, reputasi dan menjadi tujuan utama bagi aktivitas public relations dalam menjalankan perannya di perusahaan yang diwakilinya (Ruslan, 2006: 27), pubmanajemen modernlic relations juga membutuhkan perencanaan yang cukup baik dalam menyusun strategi yang akan digunakan. Public relations sebagai garda terdepan dalam membangun citra/brand image mempunyai peran penting dalam meningkatkan kepercayaan publik. Namun, dalam menentukan strategi juga dibutuhkan faktor pertimbangan tentang faktor situasi yang sedang terjadi agar mampu melewati krisis, namun tidak menutup kemungkinan sebelum krisis berakhir, perusahaan telah mencapai hasil yang diinginkan (Wasesa, 2005: 2).

\section{HASIL DAN PEMBAHASAN}

Penelitian ini dilakukan di Jampang Kulon Kecamatan Waluran Sukabumi. Jln. Cimulek Km 5. RT 01 RW 04 Desa Waluran Kecamatan Waluran merupakan salah satu bagian wilayah Kota Sukabumi dengan memiliki lahan seluas, tanah wakaf pertama yang dihibahkan dengan seluas $5.000 \mathrm{M}$, lalu sekarang di wakafkan lagi seluas 9289 meter, dan tanah yang sudah ada akte wakafnya tanah yang seluas 5.000 M.Bermodal tanah wakaf dari KH. Barizi Mubarok di Cimulek, tahap berikutnya, Program Kerja disusun, tahunan dan lima tahunan. sambil terus merayap membangun Gedung Sekolah, semulanya hanya ada 4 (empat) lokal dan pada tahun berikutnya menjadi 9 (sembilan) lokal. (Baden Barkos, 2017)

Dalam rencana pembangunan dan penyediaan sarana dan prasarana dibuat rencana 3 PELITA (Pembangunan Lima Tahunan).Pada PELITA pertama difokuskan kepada pembebasan tanah yang mencapai 5.000 meter (1/2 Hektar), berikut Master Plan mengenai tata-letak dan arsitekturalnya, sementara untuk PELITA kedua, pembangunan sarana Ibadah (Masjid), Pendidikan (Gedung Sekolah, Laboratorium, Perpustakaan, dan Asrama), serta Sarana Olah Raga, dan pada PELITA ketiga, diarahkan kepada penyediaan sarana penunjang, Aula (Gedung Pertemuan), Guest House, Kolam Renang, Lapangan Basket dan Lapangan Tennis, serta Pertamanan, sementara pada tingkat pendidikan, 
diharapkan sudah tersedia dari mulai TK sampai ke perguruan tinggi.

Pekerjaantidaksertamertamerupakankarier. Katapekerjaan (work, job, employment) menunjuk pada setiapkegiatanyang menghasilkanbarangataujasa, sedangkan kata karier(career) lebihmenunjuk pada pekerjaanataujabatan yang ditekunidan diyakinisebagaipanggilanhidup, yang meresapiseluruhalampikiran dan perasaanseseorang, sertamewarnaiseluruhgayahidupnya. Makadariitu, pemilihankarierlebihmemerlukanpersiapan dan perencanaan yang matang, bukansekedarmendapatpekerjaan yang sifatnyasementarawaktu (Widarto, 2015: 3).

\section{Proses Pelaksanaan Bimbingan Karir.}

Proses pelaksanaan bimbingan karir di SMK Al-Mussa dilaksanakan pada setiap hari senin sampai dengan hari jumat dilakukan sebelum dan sesudah proses belajar mengajar dilakukan. Sebelum proses belajar mengajar dilakukan, bimbingan karir dilaksanakan dengan materi tentang kewirausahaan, materi mengenai perencanaan karir, setelah proses belajar mengajar bimbingan karir membahas tentang planing masa depan peserta didik apakah akan melanjutkan studi ke jenjang pendidikan yang lebih tinggi, mengikuti kursus atau pelatihan, memasuki dunia kerja atau mungkin memasuki kehidupan berkeluarga (Menikah). Adapun beberapa faktor yang mendukung proses bimbingan karir dan yang menghambat dari proses pelaksanaan bimbingan karir antara lain:

Faktor Pendukung Kepala Sekolah mendukung terhadap berjalannya proses bimbingan karir di SMK Al-Mussa, karena fasilitas yang mumpuni terhadap berjalannya proses bimbingan karir, salasatunya seperti adanya ruangan kelas yang bisa dipakai untuk proses bimbingan karir berlangsung, kebijakan kepala sekolah yang mendukung terhadap proses bimbingan karir dalam menumbuhkan motivasi entrepreneurship peserta didik, Internal: Peserta didik memiliki semangat untuk berwirausaha seperti membuka jasa instal ulang laptop untuk memudahkan para peserta didik jika ada yang mempunyai masalah atau kendala dengan laptopnya seperti hang, lag, dsb Eksternal: Di sekolah tesebut diadakan bazar kewirausahaan tiap bulannya, seperti bazar buku-buku dan pakaian, ada peserta didik yang senang dengan adanya bazar kewirausahaan itu dan ada juga yang biasa-biasa saja tidak mengunjunggi bazar tersebut, sebagian peserta didik juga menjadi panitia diacara tersebut, orang tua peserta didik yang menyetujui kebijakan dari kepala sekolah dalam pembinaan bimbingan karir motivasi entrepreneurship peserta didik (Hasil wawancara hari senin 5 maret 2018 bersama bapak Baden Barkos selaku kordinator Bimbingan Karir di SMK AlMussa). 
Faktor penghambat beberapa faktor yang menghampat terhadap suksesnya proses pelaksanaan bimbingan karir dalam menumbuhkan motivasi entrepreneurship peserta didik diantaranya kurangnya minat atau antusias perserta didik dalam mengikuti proses pelaksanaan bimbingan karir di SMK AlMussa, contohnya ketika pembelajaran akan dilaksanakan 5 peserta didik berleha-leha karena terpengaruh dengan asyiknya games playstation di sekitar dekat sekolah, bahkan ada juga yang pulang sebelum jam pelajaran selesai. Internal: Sudah diberi materi tentang bimbingan karir tetapi peserta didik belum termotivasi dalam berwirausaha dan peserta didik kurang semagat dalam merencanakan karirnya, Ekternal: Belum ada materi sehingga 11 peserta didik bingung dalam memulai berwirausaha atau perencanaan karirnya, karena dipengaruhi oleh gadget, games dan alat elektronik lainnya, sehingga membuat para peserta didik menjadi bermalas-malasan dalam merencanakan perencanaan karir untuk masa depannya, dan yang dilakukan oleh mereka tauran dengan sekolah-sekolah lain, mencorarat-coret tembok sekolah lain, merokok, dll. (Hasil wawancaraharisenin 5 maret 2018 bersama bapak baden barkos selakukordinatorbimbingankarir di SMK Al-Mussa).

Pilihanjabatanmerupakansuatuperpaduandarianekafaktor pada individusendirisepertikebutuhan, sifatsifatkepribadian,sertakemampuanintelektual, dan banyakfaktor di luarindividu,sepertitarafkehidupansosial-ekonomikeluarga, variasituntutanlingkungankebudayaan, dan kesempatan/kelonggaran yangmuncul. Titikberatdarihal-haltersebut di atasterletak pada faktorfaktor pada individusendiri (Widarto,2015: 3) .

PencapaianAkhir yang diharapkan Sekolah Menengah Kejuruan Al-Mussa antara lain: (a) Meningkatkan kualitas keimanan dan ketaqwaan. (b) Suasana harmonis antara lembaga, orang tua siswa, masyarakat dan instansi terkait. (c) Meningkatkan disiplin sebagai perwujudan usaha serius dalam menekuni semua ilmu. (d) Budaya gemar membaca merupakan suatu tuntutan untuk meningkatkan prestasi belajar.

Sistem belajar mengajar disusun oleh kepala sekolah, semua waka yang ada (waka kurikulum, waka kesiswaan, waka humas, waka sumber daya manusia, waka keuangan) dan guru. Di sini dibentuk sebuah tim mata pelajaran, dan koordinatornya dari tim tersebut yang dipilih secara musyawarah. Pada tahap perencanaan ini, pihak industri ikut terlibat dan sangat berperan aktif dalam memberikan masukan dalam perencanaan pelaksanaan pembelajaran.

Sistem pembelajaran di Sekolah Menengah Kejuruan Al-Mussa yakni 
sebagai berikut: peserta didik pada pukul 07:00 WIB Sudah harus berada di sekolah untuk melakukan shalat duha dan tadarus sama-sama sampai pukul 08:00 WIB, satelah pukul 08:00 WIB lalu semua peserta didik memasuki ruang kelasnya masing-masing untuk melaksanakan proses belajar mengajar sampai pukul 10.00 WIB jam istirahat, waktu istirahat 20 menit. Lalu masuk lagi sampai pukul 12:00 WIB, setelah pukul 12:00 WIB peserta didik melakukan shalat duhur berjamaah, pada pukul 12:30 peserta didik memasuki ruangan kelas kembali melaksanakan proses belajar mengajar sampai pukul 02:00, setelah itu peserta didik di bebaskan jika ada yang mau melaksanak eksul atau pulang ke rumahnya masing-masing.

Adapun materi yang diberikan oleh guru Bk kepada para peserta didik ketika kegiatan bimbingan yaitu pada pertemuan pertama pembimbing menanyakan mengenai perkembangan apa yang sudah dilakukan para peserta didik pada hari itu, kemudian pembimbing memberikan pengarahan jika peserta didik yang mengalami permasalahan atau kesulitan dalam melaksanakan pengembangan dirinya agar peserta didik bisa menyimpulkannya sendiri,dan materi yang disampaikan nya dalam bentuk tayangan slide show tentang perencanaan karir, enam antaranya berjudul: (a) Perencanaan karir. (b) Tips mencari kerja. (c) Syarat untuk kerja dan penjurusan karir peserta didik. (d) Pengelolaan karir sendiri. (e) Mantap di pilihan karir. (f) Menumbuhkan jiwa kepemimpinan sejati. g) teori holland.

Guru pembimbing adalah guru yang bertugas di bagian BK (Bimbingan Konseling) di sekolah, Tugas pokok guru pembimbing adalah untuk membimbing para peserta didik di sekolah. Dengan adanya guru pembimbing, diharapkan peserta didik yang berkelakuan menyimpang dapat dibina sehingga dapat menjadi lebih baik lagi. Dan di SMK Al-MUSSA terdapat 3 guru BK tetapi guru Bk yang diwawancarai peneliti satu guru BK yaitu guru BK kelas XII (Dua Belas) dengan profil sebagai berikut: Nama lengkap:Baden Barkos SPd.I Tempat tanggal Lahir:Sukabumi 28 Desember 1973 dengan riwayat pendidikan SD di SDN Tegalega (Waluran) masuk pada tahun 1981 lulus pada tahun 1987, SMP di SMPN Jampang Kulon masuk pada tahun 1987 lulus pada tahun 1990, SMA di SMAN Jampang Kulon masuk pada tahun 1990 lulus pada tahun 1993, Perguruan Tinngi:(D3) AMIK CBI Sukabumi masuk pada tahun 1993 lulus pada tahun 1996 (S1) STAIN Kudus masuk pada tahun 1997 lulus pada tahun 2001.

Pada sekolah kejuruan ini terdapat dua fase pelaksanaan pendidikan yang berlangsung di sekolah dan industri. Pertama yang berlangsung di sekolah pada semester satu, dua, tiga dan enam. Sedangkan di industri berlangsung saat peserta didik pada semester empat dan lima untuk menerapkan kemampuan dan 
keahliannya berdasarkan jurusan masing-masing.

Proses pembelajaran di SMK Al-Mussa menggunakan berbagai metode yang sesuai dengan dengan jurusan yang ada. Metode yang digunakannya yaitu: (1) Metode Direct. (2) Metode Observasi. (3) Metode Konsultasi. (4) Metode Demostrasi. Selama proses pembelajaran berlangsung guru selalu mengawasi dan membenarkan pekerjaan peserta didik serta memonitor untuk menentukan tempat Prakerin. Saat menutup pembelajaran, guru memberikan tindak lanjut serta saran-saran untuk memperluas wawasan yang berhubungan dengan materi pelajaran yang telah dibahas, penguatan, stimulus, serta memotivasi kepada peserta didik.

Tempat dan kegiatan-kegiatan bimbingan karir diwujudkan di ruangan kelas, luar kelas dan ruang bimbingan. Pertama pelaksanaan yang diberikan di dalam kelas pelaksanaan yang bersifat umum dan melibatkan semua peserta didik. Pelaksanaan yang diberikan berupa penjelasan tentang apa saja mengenai karir. Kedua pelaksanaan bimbingan karir yang dilakukan di ruang bimbingan konseling mengadakan rapat koordinasi tentang pelaksanaan bimbingan karir bersama guru atau peserta didik yang sudi membantu. Ketiga pelaksanaan yang diberikan di luar kelas bimbingan yang dilakukan di asrama ada perorangan atau secara kelompok dan kegiatanya bersifat tidak formal. Oleh karena itu guru bk tinggal bersama peserta didik dan menjadi pengasuh di asrama agar mereka sering mendapatkan bimbingan.

Data penelitian ini menggunakan metode direct, observasi dan wawancara terhadap informan atau orang yang mempunyai informasi tentang data penelitian. Untuk memperoleh data Bimbingan Karir SMK Al-Mussa peneliti mewawancarai pembimbing dan peserta didik yang mempunyai peran sebagai informan, data dari hasil wawancara antara lain adalah Kondisi peserta didik yang dirasakan oleh guru BK beliau mengatakan bahwa sesudah diadakannya bimbingan karir dengan jumlah peserta didik kelas XII (38 orang) dari 38 peserta didik tersebut 16 peserta didik masih belum mampu menentukan karir yang dikehendaki sesuai dengan kemampuan yang dimilikinya, 22 peserta didik memahami betapa penting sebuah karir untuk menentukan masa depan yang cerah baginya kelak dan setelah diadakannya bimbingan karir juga yang 22 peserta didik sudah dapat menentukan karir yang diinginkannya, bukan menjadi hal yang menakutkan dan membingungkan lagi bagi mereka sekarang, karena guru BK sudah memberi bimbingan atau arahan kepada mereka tentang karir. Sebelum diadakannya bimbingan karir 16 peserta didik kurang bersemangat dalam berkarir atau berwirausaha seperti kurang mampu dalam menentukan karir yang dikehendakinya dan peserta didik juga kurang memahami betapa 
pentingnya sebuah karir bagi masa depannya karena faktor lingkungan, pengaruh games online, teman sebaya, dan gadget.

Tempat dan kegiatan-kegiatan bimbingan karir diwujudkan di ruangan kelas, luar kelas dan ruang bimbingan. Pelaksanaan yang diberikan di dalam kelas Pelaksanaan yang bersifat umum dan melibatkan semua peserta didik. Pelaksanaan yang diberikan berupa penjelasan tentang apa saja mengenai karir. Menggunakan media yang disediakan yaitu tayangan slide show, video dan papan putih. Meminta peserta didik menuliskan tentang cita-cita dan karir yang diingini, matapelajaran yang diminati, hobi dan bakat yang ada pada diri peserta didik. Peserta didik juga pernah membuat sosiodrama yaitu memainkan peran sebagai seorang pejabat, pengusaha, guru, dokter dan lain-lain jenis pekerjaan.

Pelaksanaan bimbingan karir yang dilakukan di ruang bimbingan konseling Mengadakan rapat koordinasi tentang pelaksanaan bimbingan karir bersama guru atau peserta didik yang sudi membantu, bekerjasama dengan mahasiswa yang magang, mengadakan konsultasi dengan pihak-pihak yang terlibat dalam pelaksanaan bimbingan karir, mengolah data yang didapatkan dari peserta didik, menyusun program bimbingan karir dan mengadakan pelaksanaan konseling karir perorangan atau kelompok.

Pelaksanaan yang diberikan di luar kelas Bimbingan yang dilakukan di asrama sama ada perorangan atau secara kelompok dan ianya bersifat tidak formal. Oleh karena guru bk tinggal bersama peserta didik dan menjadi pengasuh di asrama maka mereka sering mendapatkan bimbingan.

Untuk mengetahui lebih jelas proses pelaksanaan bimbingan karir di SMK Al-MUSSA dalam menumbuhkan motivasi entrepreneurship peserta didik, dapat dilihat dari waktu dan tempat pelaksanaan kegiatan bimbingan, karir (pembimbing), konseli (terbimbing), metode, materi, media, tahap atau proses konseling individu, dan evaluasi kegiatan.

Dari hasil wawancara kepada pihak pengajar Bapak Ridwan bahwasanya waktu pelaksanaan bimbingan karir individu yaitu setelah proses belajar mengajar pada pukul 14.00 WIB dilaksanakan di ruangan khusus yang berdekatan dengan ruangan tempat berkumpulnya peserta didik sedangkan waktu pelaksanaan bimbingan karir kelompok dilakukan sebelum proses belajar mengajar pada pukul 07.00 WIB setelah dilaksanakan nya shalat dhuha bersama dan tadarus.

Sekolah Menengah Kejuruan Al-Mussa Jampang Kulon Kabupaten Sukabumi merupakan sarana pelayanan lembaga pendidikan yang salah satu tujuannya membantu pemerintah dalam merealisasikan hak anak untuk mendapatkan penghidupan dan pendidikan yang layak bagi anak yang kurang 
mampu dalam menuntut ilmu, peserta didik yang sekolah di SMK Al-Mussa di berikan pengetahuan-pengetahuan serta pendidikan moral, etika dan agama di bawah pengawasan guru BK yang di tunjuk oleh ketua yayasan Al-Mussa.

Adapun indikator entrpreneurship disana yaitu: Penuh percaya diri: yaitu kemampuan peserta didik ketika menjalankan program kewirausahaan yang ada di SMK Al-Mussa penuh percaya diri ketika melaksanakan wirausaha contohnya saat mereka bejualan atau mengembangkan potensi yang dimiki mereka tidak malu dengan teman-teman sekitarnya, hal itu untuk dapat memahami dan meyakini seluruh potensi yang dimilikinya agar dapat dipergunakan dalam menghadapi penyesuaian diri dengan lingkungan hidupnya.

Memiliki inisiatif: yaitu hal positif pada peserta didik, contohnya 6 orang peserta didik yang memiliki keahlian yang sama, yang 3 cenderung pasif cenderung menyimpan keinginan mengambil bidang yang digemari dalam hati tetapi enggan untuk mengungkapkannya dan juga menunggu perintah dari orangtuanya sementara yang 3 (tiganya) lagi bersemangat dan memiliki inisiatif dalam membantu perusahaan orangtuanya, diantaranya: menjaga toko photocopyan, bidang pertanian, showroom mobil dan motor.

Memiliki motif barprestasi: yaitu motif berprestasi dalam bidang yang diambilnya contohnya barra sukses dalam menjalankan bidang pertaniannya, dia mampu membantu mengolah tanah-tanah kedua orang tuanya dengan hasil padi yang ditanamnya selalu bagus atau subur, itu sebagai dorongan yang berhubungan dengan prestasi peserta didik yakni menguasai, mengatur lingkungan sosial, atau fisik, mengatasi rintangan atau memelihara kualitas sekolah yang tinggi, bersaing melebihi prestasi yang lampau dan mempengaruhi orang lain.

Memiliki jiwa kepemimpinan: yaitu memiliki jiwa kepemimpinan atau juga disebut dengan Leadership, sifat seseorang yang dapat mengendalikan, mengatur seseorang dan sekelompok manusia dalam sebuah organisasi, seperti sekolah, tempat kerja, keluarga, dll. ujar guru BK ada 6 orang yang memiliki jiwa kepemimpinan pada kelas XII yaitu 4 laki-laki dan 2 perempuan salasatu contohnya barli dapat mengarahkan adiknya ketika adiknya melakukan kesalahan berkelahi disekolah dengan temannya barli dapat mengendalikan emosi adiknya dan setelahnya menemui guru BK untuk mengakui kesalahan dari adiknya, itu adalah suatu sifat yang dianugrahkan Allah kepada manusia, yang tidak semua manusia memiliki sifat ini.

Berani mengambil resiko dengan penuh perhitungan Resiko: yaitu bagi para wirausaha bukanlah sebagai suatu hambatan untuk meraih kesuksesan tetapi 
dijadikan sebagai suatu tantangan. Contohnya ketika Sajidan ketika menyablon kaos pelanggan dan sablonan tersebut kurang rapi atau tidak disesuai dengan keinginan pelanggan sajidan mengganti sablonan tersebut dengan yang baru, karena menurut dia wirausaha adalah orang yang lebih menyukai hal-hal yang menantang untuk lebih mencapai kesuksesan dalam hidupnya.

Karir seseorang akan berkembang bukanlah semata karena faktor nasib, justru faktor yang paling dominan dalam memuluskan karir seseorang adalah faktor usaha. Maksudnya dengan usaha yang keras dari karyawan yang bersangkutan untuk maju, mengembangkan diri dan menjadi karyawan yang handal.

Media yang digunakan dalam pelaksanaan bimbingan karir tersebut yaitu ruangan sederhana yang terdiri dari satu kursi untuk konselor dan satu kursi untuk konseli, buku tulis dan pulpen jika ada anak yang masih enggan untuk berbicara langsung dan lebih berani ketika permasalahannya itu ditulis.

Tujuan bimbingan Karir di sekolah SMK Al-Mussa adalah untuk membantu para peserta didik memiliki keterampilan dalam mengambil keputusan mengenai karir di masa depannya, untuk mencapai hal itu maka diperlukan adanya pemahaman dari peserta didik dalam pengamatan lingkungan sekitar, agar peserta didik dapat menentukan masa depannya.

\section{Program Bimbingan Karir}

Untuk memperoleh data mengenai Program Bimbingan Karir dalam Menumbuhkan Motivasi Entreprenership Peserta Didik, maka penulis mengadakan wawancara dengan Guru BK di SMK Al-Mussa Jampang Kulon Kabupaten Sukabumi. Adapun program-program bimbingan karir yang dilaksanakan di SMK Al-Mussa menurut Bapak Baden Barkos antara lain :

Pertama melalui program latihan keterampilan peserta didik bisa memilih diantaranya ada wirausaha: menjahit, montir/bengkel mobil dan motor, pangkas rambut, pertanian, sablon, kursus service hp, install ulang laptop, tata boga. Dll, peserta didik dapat memilih wirausaha tersebut. Bapak Baden barkos mengatakan Sekolah Menengah Kejuruan Al-Mussa Jampang Kulon Kabupaten Sukabumi salasatu sekolah yang dalam kemajuannya tidak hanya memupuk para peserta didiknya terhadap keilmuan kejuruan saja, namun di Sekolah Menengah Kejuruan ini juga mengajarkan kepada para peserta didiknya menjadi entrepereneur dari sejak remaja, agar nantinya para peserta didik ketika sudah selesai menempuh pendidikan di Sekolah Menengah Kejuruan Al-Mussa ini tidak lagi bingung dan tak tau akan bagaimana dengan masa depannya kelak. Tidak ada syarat untuk masuk ke setiap bidang tersebut ujar beliau yang penting ada 
kemauan dulu dari peserta didik mereka bebas mau mengambil bidang apapun yang digemarinya.

Kedua melalui program konseling melalui program konseling gunanya untuk melakukan pendekatan secara lebih intens dan dekat dengan peserta didik, dengan diadakannya program konseling yang diselenggarakan setiap satu minggu sekali yaitu pada hari kamis, program konseling tersebut dilakukan dengan berbagai materi yang berkaitan dengan karir, motivasi, entrepreneurship dan melatih kepercayaan diri.

Ketiga kunjungan ke tempat-tempat industri program ini dilakukan dua bulan satu kali, tujuan melakukan kunjungan industri ini agar menambah wawasan dan ilmu pengetahuan tentang berbagai macam ilmu teknologi sesuai dengan bidang keahlian kami (komunikasi dan informasi), program kunjungan ke tempat industri juga lebih meningkatkan pemahaman tentang dunia kerja peserta didik, agar menambahpemahamanterhadapteknologi dan bidangkerja.

Peserta didikharusdapatmengidentifikasikanalternatif caracara mencapaitujuan-tujuanpendidikan yang membantudalamproses perencanaanpendidikan.

Menggambarkanbentukbentukutamameneruskanpendidikansesudahsekolahlanjut an(misalnyamagang, pelatihan-pelatihan, kursus, sekolahmiliter,perguruantinggi), dan mencatat yang paling berhubungandenganpemilihananpekerjaan. Mengembangkanrencanarencanatersebutuntukmerencanakantujuanakhir (Widarto, 2015: 26).

\section{Hasil Dari Bimbingan Karir}

Setelah peneliti memaparkan proses dan program bimbingan karir dalam menumbuhkan motivasi entrepreneurship peserta didik SMK Al-Mussa Jampang Kulon Kabupaten Sukabumi ada beberapa kemampuan-kemampuan para peserta didik yang tidak bisa dikembangkan dikarenakan kurangnya rasa percaya diri klien (peserta didiki, maka sekarang peneliti akan memaparkan hasil kondisi para peserta didik yang telah dicapai dalam pelaksanaan kegiatan bimbingan tersebut sesuai dengan wawancara yang telah dilaksanakan.

Pertama pemahaman minat berdasarkan wawancara dengan para peserta didik di Sekolah Menengah Kejuruan Al-Mussa, mereka mulai menemukan bidang karir atau keterampilan yang mereka minati, sesuai dengan pernyataan Bapak Baden Barkos selaku guru BK di SMK Al-Mussa yang mengatakan bahwa peserta didik dapat memilih kegiatan karir yang ingin mereka ikuti sesuai dengan keinginan yang mereka minati. 
Kedua pengetahuan mengenai dunia kerja setelah mengikuti berbagai jenis bimbingan karir yang dilaksanakan di SMK Al-Mussa, peserta didik mulai mengenal banyak bidang yang dapat mereka jadikan referensi untuk bekerja nantinya. Sebelumnya para pesertadidik mengira bahwa lapangan pekerjaan hanya untuk orang-orang berpendidikan, namun sekarang mereka mulai memahami bahwa ada lapangan pekerjaan lain yang dapat mereka masuki atau bahkan mereka buat sendiri yaitu dengan menjahit, montir/bengkel mobil dan motor, pangkas rambut, pertanian, sablon, kursus service hp, install ulang laptop, tata boga, dan masih banyak lagi. Pengetahuan mengenai dunia kerja sendiri memang penting bagi mereka sebagai salasatu bekal yang harus mereka miliki setelah keluar dari Sekolah Menengah Kejuruan Al-Mussa nantinya.

Ketiga positif terhadap dunia kerja para peserta didik di SMK Al-Mussa selalu berpikir bahwa mereka akan sulit dalam memasuki dunia kerja karena alasan mereka tidak mempunyai kemampuan apa-apa, kemudian setelah mereka mengetahui banyak tentang lapangan kerja yang dapat mereka masuki, mereka mulai paham dan tidak menganggap lagi bahwa dunia kerja hanya untuk orangorang yang pintar dan mempunyai banyak keahlian. Mereka juga sebelumnya tidak pernah berpikir untuk bekerja mereka seringkali merasa bahwa setelah keluar dari SMK Al-Mussa nantinya akan menjadi pengangguran dan susah dalam mencari pekerjaan. Namun sekarang mereka sangat bersemangat bila membahas pekerjaan apa yang akan mereka tekuni nanti, karena mereka mulai berfikir positif terhadap dunia kerja dan berpikir bahwa mereka juga bisa sukses dan bekerja menjadi apapun yang mereka mau asalkan mereka berusaha keras dan belajar.

Keempat merencanakan masa depan. mampu merencanakan masa depan merupakan salasatu tujuan dari bimbingan karir di SMK Al-Mussa, dengan diberikannya berbagai pembinaan kemandirian bimbingan karir dan pelatihan keterampilan diharapkan para peserta didik dapat merencanakan masa depan mereka dari sekarang. Saat mewawancarai salasatu peserta didik yang bernama melya berusia 18 tahun dia pernah mengikuti kegiatan tataboga. Ketika mengikuti pelatihan tataboga, dia mendapat banyak ilmu dan pengalaman yang menyenangkan, sehingga dia mengaku terinspirasi untuk membuat toko kue atau restoran sendiri saat dia sudah lulus dari SMK Al-Mussa, meskipun nantinya dia tidak bisa mewujudkan cita-citanya itu, Melya tetap ingin bekerja di bidang tataboga dan memanfaatkan sertifikat dari kegiatan tataboga itu untuk dijadikan modal baginya saatmencaripekerjaankelak.

Setiap orang memilikipotensi dan kemampuan yang luarbiasa. Namundibutuhkanwaktupanjanguntukmencapaisemuahal yang 
mampudikerjakan. Sayangnya, manusiahanya punya satukesempatansajadalamhidupinikarenawaktuterusberjalan dan takbisakembali,Penyesalan terjadi karena salah langkah atau keliru dalam bertindak.Manusia yang jatuh dalam kesalahan yang sama karena gagal belajardari sebuah pengalaman. Adapula yang terjebak dalam trauma dansulit bangkit kembali untuk mengembangkan diri (Widarto, 2015: 104).

Berdasarkan hasil penelitian di lapangan tersebut, dapat dilihat bahwa setiap jenis bimbingan karir yang diadakan di SMK Al-Mussa mampu menginspirasi dan memberi semangat kepada para peserta didik untuk tetap percaya diri bahwa mereka bisa memasuki berbagai jenis dunia kerja meskipun mereka tidak mempunyai banyak keahlian. Jenis bimbingan karir yang dilaksanakan di SMK Al-Mussa memang agak berbeda dengan jenis bimbingan yang dilaksanakan di sekolah lainnya, namun jenis bimbingan karir tersebut memang disesuaikan dengan kondisi lapangan dan kebutuhan para pesertadidik di SMK Al-Mussa.

\section{PENUTUP}

Berdasarkan penelitian diatas maka dapat disimpulkan sebagai berikut:

Pertama, proses bimbingan karir di SMK Al-Mussa mengarah kepada Teoritik salasatunya sepeti teori kejuruan dan Praktik yaitu dalam melaksanakan program-progrsm yang ada di Sekolah. Jenis bimbingan karir yang dilaksanakan nya memang berbeda dengan bimbingan karir yang sering diadakan di sekolah atau lembaga-lembaga lain. Meskipun demikian, jenis bimbingan karir yang diselenggarakan tetap memuat jenis layanan karir pada umumnya. Karena bimbingan karir di SMK Al-Mussa mempunyai tujuan-tujuan bimbingan karir pada umumnya. Tujuan bimbingan karir sendiri meliputi pemahaman minat dan bakat, mampu merencanakan masa depan, mengenalkan berbagai bidang pekerjaan dan membekali peserta didik dengan berbagai keterampilan serta pengetahuan agar dapat dimanfaatkan oleh mereka ketika sudah keluar dari SMK Al-Mussa dan memulai kehidupan mereka di lingkungan masyarakat seperti biasanya.

Kedua, kondisi peserta didik di SMK Al-Mussa sebelum mengikuti proses bimbingan karir hampir kebanyakan peserta didik masih kebingungan dalam menentukan karir buat masa depannya, tetapi setelah mengikuti bimbingan karir, kondisi peserta didik yang dirasakan oleh guru BK bahwa sesudah diadakannya bimbingan karir dengan jumlah peserta didik kelas XII (38 orang) dari 38 
peserta didik tersebut 16 peserta didik masih belum mampu menentukan karir yang dikehendaki sesuai dengan kemampuan yang dimilikinya, 22 peserta didik memahami betapa penting sebuah karir untuk menentukan masadepan yang cerah baginya kelak dan setelah diadakannya bimbingan karir juga yang 22 peserta didik sudah dapat menentukan karir yang diinginkannya.

Ketiga, hasil yang dicapai dari proses Bimbingan Karir di SMK AlMubarokatussa'adillah yakni dimana adanya suatu proses pemberian bimbingan oleh guru BK terhadap peserta didik dalam menentukan pemilihan karir yang akan ditempuhnya sesudah peserta didik melaksanakan jenjang pendidikannya, adanya bimbingan karir ini tentu para peserta didik akan siap ketika mereka melanjutkan kehidupan didalam bermasyarakat, dengan indikator Entrepreneurship : a) Inovatif yang artinya memperkenalkan suatu yang baru, b) Kreatif yang artinya memiliki kemampuan untuk menciptakan atau menghasilkan sesuatu yang baru, dan c) Produktif yang berarti kemauan untuk menghasilkan atau banyak mendatangkan sesuatu hasil.

Materi yang diberikan dalam Bimbingan Karir untuk para peserta didik di SMK Al-Mubarokatussa'adillah yaitu materi yang disampaikan dalam layanan informasi dalam bentuk tayangan slide show tentang perencanaan karir, tujuh antaranya sebagai Berikut: a) Perencanaan karir. b) Tips Mencari Kerja. c) Syarat untuk bekerja dan penjurusan karir peserta didik. d) Pengelolan karir sendiri. e) Mantap di pilihan karir. f) Menumbuhkan jiwa kepemimpinan sejati. g) Teori holland. Program latihan keterampilan yang diadakan di SMK Al-Mussa yaitu peserta didik bisa memilih diantaranya ada wirausaha: menjahit, montir/bengkel mobil dan motor, pangkas rambut, pertanian, sablon, kursus service hp, install ulang laptop, tata boga, Dll.

Saran dari peneliti yaitu: (1) Sebaiknya menyediaan fasilitas yang mendukung serta mengikuti work shop keterampilan yang bakal menunjang karir para peserta didik, (2) Sebaiknya memperluas kemitraan baik itu pemerintah maupun perusahaan, (3) Sebaiknya pemerintah setempat harusnya ikut andil dalam adanya pelaksanaan bimbingan karir dalam meningkatkan life skill peserta didik ini, (4) Sebaiknya mewajibkan seluruh peserta didik agar selalu mengikuti pelaksanaan kegiatan dan program-program bimbingan karir ini, karena dengan megikuti kegiatan bimbingan karir itu bisa menunjang dan meningkatkan life skill yang dimiliki oleh para peserta didik.

\section{DAFTAR PUSTAKA}


Ardana, I. K., Mujiati, N.W., \& Utama, I.W.M. (2011). Manajemen Sumber Daya Manusia. Yogyakarta: Graha Ilmu.

Arifin, I. (2008). Bimbingan Konseling Islam (al-Irsyad wa al-Tawjih al-islam) Berbasis Ilmu Dakwah. Imu Dakwah: Academic Journal for Homiletic Studies [Online], 4.11: 27-42. Web. 3 Jul. 2018

Defriyanto dan Purnamasari, N. (2016). Pelaksanaan layanan bimbingan konseling karir dalam meningkatkan minat siswa dalam melanjutkan studi kelas XII di SMA Yadika Natar dalam Konseli: Jurnal Bimbingan dan Konseling 03(2) 271-285.

Dewi, Q. (2016). Strategi Komunikasi pada Pasar Modal Syariab Berbasis Cyber Public Relations. Ilmu Dakwh: Academic Journal for Homiletic Studies [Online]. 10.1 (2016): 17-36.

Hendro. (2011). Dasar-dasar kewirausahaan: Panduan Bagi siswa untuk Mengenal, Memahami, dan Memasuki Dunia Bisnis Jakarta: Airlangga.

Juwitaningrum, I. (2016). Program Bimbingan Karir untuk Meningkatkan Kematangan Karir Siswa SMK dalam PSIKOPEDAGOGLA Jurnal Bimbingan dan Konseling 2(2).

Khairun, D. Y., Sulastri, M. S., \& Hafina, A. (2016). Layanan bimbingan karir dalam peningkatan kematangan eksplorasi karir siswa dalam Jurnal Penelitian Bimbingan dan Konseling 1(1).

Mu'awanah, E., \& Hidayah, R. (2012). Bimbingan Konseling Islami di Sekolah Dasar Jakarta : PT. Bumi Aksara.

Tohardi, A. (2002). Pemahaman Praktis Management Sumber Daya Manusia, Cetakan I, Penerbit CV. Mandar Maju, Universitas Tanjung Pura, Bandung.

Rahma, U. (2015). Bimbingan Karir Siswa Malang: UIN Maliki Press.

Sani, D. (2018). Pengaruh Layanan Informasi Karir terhadap Minat Berwirausaha dalam Irsyad: Jurnal Bimbingan, Penyuluban, Konseling, dan Psikoterapi Islam 6(3).

Setiawaty, T., Diningrat, K., \& Fajar, D.A. (2017). Bimbingan Karir Melalui Kegiatan Keterampilan dalam Meningkatkan Kemandirian Wargabinaan dalam Irsyad: Jurnal Bimbingan, Penyuluban, Konseling, dan Psikoterapi Islam 5(4).

Sofiah, S.(2018). Aplikasi Fungsi Bimbingan Karir dan Minat Siswa Melanjutkan Pendidikan ke Perguruan Tinggi dalam Irsyad: Jurnal Bimbingan, Penyuluban, Konseling, dan Psikoterapi Islam 6(1).

Wasesa, S. A. (2005). Strategi Public Relation: Bagaimana Strategi Pubic Relationsdari 36 merek Global dan Lokal Membangun Citra, mengendalikanKrisi danmerebut hati 
B. Hakiki

Konsumen. Jakarta. PT. Gramedia Pustaka Utama.

Widarto. (2015). Bimbingan Karir dan Tips Berkarir. Yogyakarta.

Winkel, W.S. \& M.M. Sri Hastuti. (2005). Bimbingan dan Konseling di Institusi

Pendidikan. Yogyakarta: Media Abadi.

Winkel, W.S. (1997). Bimbingan dan Konseling. Jakarta: Grasindo. 